\title{
Structure and diversity of restingas along a flood gradient in southeastern Brazil ${ }^{1}$
}

\author{
Luiz Fernando Silva Magnago ${ }^{2,6}$, Sebastião Venâncio Martins ${ }^{3}$, \\ Carlos Ernesto Goncalves Reynaud Schaefer ${ }^{4}$ and Andreza Viana Neri ${ }^{5}$
}

Received: 23 August, 2011. Accepted: 13 August, 2013

\begin{abstract}
This study aimed to relate changes in structure and species diversity with edaphic variables (soil type and flooding regime) in a gradient of forest formations within the Brazilian restingas (coastal woodlands). The study was carried out in the Jacarenema Municipal Natural Park, in the city of Vila Velha, in the Espírito Santo State, Brazil. We evaluated the structure of shrub and tree components by sampling 80 plots of $5 \times 25 \mathrm{~m}$ each, equally distributed among four forest types (well-drained, transitional, floodplain and flooded). We included all individuals with a $\geq 3.2 \mathrm{~cm}$ diameter at breast height. From each plot, soil samples (for chemical and physical analysis) were collected at a depth of 0-10 $\mathrm{cm}$. We identified a significant fertility gradient (of soil nutrient availability) and a strong influence of groundwater on each forest type. We also found significant differences among the forest types in terms of individual basal area and height, as well as density. Diversity increased along the environmental gradient, from flooded to well-drained forest. We conclude that variations in structure and diversity among the four forest types were correlated with the flooding regime, as well as with chemical and physical characteristics of the soil.
\end{abstract}

Key words: Espírito Santo; forest ecology; soil gradient; species selectivity; edaphic variations

\section{Introduction}

The restinga (coastal woodland) ecosystem in Brazil results from marine transgressions and regressions that created system of sand bars during the Quaternary, well inland during the Pleistocene and closer to the coastline during the Holocene (Martin et al. 1997). The formation of these sand ridges led to the appearance of lakes, lagoons and bays (Bigarella 2001). In some sections of flooded areas, which usually occur between the sand ridges, the deposition of organic matter resulted in peatlands (Martin et al. 1997).

In general, the soils that compose the restinga ecosystem are chemically poor, and the main sources of nutrients are salt spray deposition (Leão \& Dominguez 2000; Scarano 2002) and flooding (Magnago et al. 2010). The predominant classes of soil in this ecosystem are Spodosols (podzols) and Quartzarenic Neosols (Gomes et al. 1998; Rossi, 1999), and the former often undergo an incipient process of podzolization and display intermediate characteristics for podzols (Gomes et al. 2007). However, Gleysols and Histosols also occur in this ecosystem and are associated with bottom- land environments (between the sand ridges), where the water table reaches the soil surface (Magnago et al. 2010). Therefore, the restinga presents a diversified environmental mosaic, composed of different types of soils and influenced by the groundwater fluctuation. Therefore, there is great interest in this ecosystem as an environment within which the distribution of vegetation in relation to variations in these abiotic factors can be investigated.

The relationship between soil fertility with species composition and vegetation structure has been evaluated in various studies (Huston 1980; Tilman 1986; Stevens \& Carson 1999) and has been shown to be a determinant of biomass gradients and vegetation structures (Tilman 1982). In environments subjected to flooding, there are alterations in oxygen availability, as well as in the physical and chemical characteristics of the soil (Pezeshki 2001), which promotes the selective establishment for plant species (Ivanauskas et al. 1997; Budke et al. 2007).

In restingas, the plant formations in depressions differ from those on the sand ridges because of flooding, which can lead to potentially limiting conditions, such as species

\footnotetext{
${ }^{1}$ Based on the Master's dissertation of the first author

${ }^{2}$ Universidade Federal de Viçosa, Programa de Pós Graduação em Botânica, Viçosa, MG, Brazil

${ }^{3}$ Universidade Federal de Viçosa, Departamento de Engenharia Florestal, Viçosa, MG, Brazil

${ }^{4}$ Universidade Federal de Viçosa, Departamento de Solos e Nutrição de Plantas, Viçosa, MG, Brazil

${ }^{5}$ Universidade Federal de Viçosa, Departamento de Biologia Vegetal, Viçosa, MG, Brazil

${ }^{6}$ Author for correspondence: luiz_fsm@hotmail.com
} 
selectivity and alterations in the structural characteristics of the vegetation (Blom \& Voesenek 1996; Magnago et al. 2010). Conversely, the tops of sand ridges present limitations to the establishment of species because of their low nutrient availability and water deficit caused by the low soil water retention (Scarano 2002; Magnago et al. 2010).

Considering that the restinga is an ecosystem that presents forests with differences in the nutrient availability of the soil and variations in the water table (Magnago et al. 2010), the aim of this study was to determine which edaphic factors influence the structure and species diversity of the forest formations within this ecosystem. We tested the following hypotheses: there is an edaphic gradient (of drainage, physical characteristics and chemical characteristics) in these forests; the species diversity varies among these forests and is correlated with the edaphic variables; and the vegetation structure (basal area, density and height) differs among these forests and is correlated with the edaphic variables.

\section{Material and methods}

\section{Study site}

The study site was the Jacarenema Municipal Natural Park (20 $26^{\prime} 25^{\prime \prime}$; $\left.40^{\circ} 18^{\prime} 45^{\prime \prime} \mathrm{W}\right)$, which is located in the Barra do Jucu district of the city of Vila Velha, in the Espírito Santo State, Brazil (Fig. 1). The park covers 307 hectares (IPEMA 2005). According to the Köppen climate classification system, the climate of the region is type Aw, tropical hot and humid with a rainy season (summer) and a dry season (winter). According to data obtained from the Brazilian National Institute of Meteorology for the state capital of Vitória, the average annual precipitation is $1136 \mathrm{~mm}$ and the average annual temperature is $24.8^{\circ} \mathrm{C}$.

The forests studied here occur adjacent to each other along the left (east) bank of the Jucu River, in a gradient formed from the area between ridges (where the Jucu river flows) to the internal (continental) of the sand ridge. This condition leads to a differential influence of the water table on these forests, which are associated with different soils (Tab. 1) (Magnago et al. 2010). The classification of the forest formations followed the terminology proposed by Pereira (2003): well-drained, transitional, floodplain and flooded.

\section{Structure and diversity of the shrub and tree communities}

The quantitative analysis of shrub and tree species was systematically performed in 80 plots of $5 \times 25 \mathrm{~m}\left(125 \mathrm{~m}^{2}\right)$ each, $2 \mathrm{~m}$ apart, as recommended by Mueller-Dombois \& Ellenberg (1974), in a total sampled area of 1 ha. In each forest formation, 20 plots were established parallel to the bank of the Jucu river. We made an effort to represent the core areas of each forest, and thus no distances were established for the allocation of plots among the physiognomies. All individuals with $\mathrm{a} \geq 3.2 \mathrm{~cm}$ diameter at breast height $(1.30 \mathrm{~m}$ from

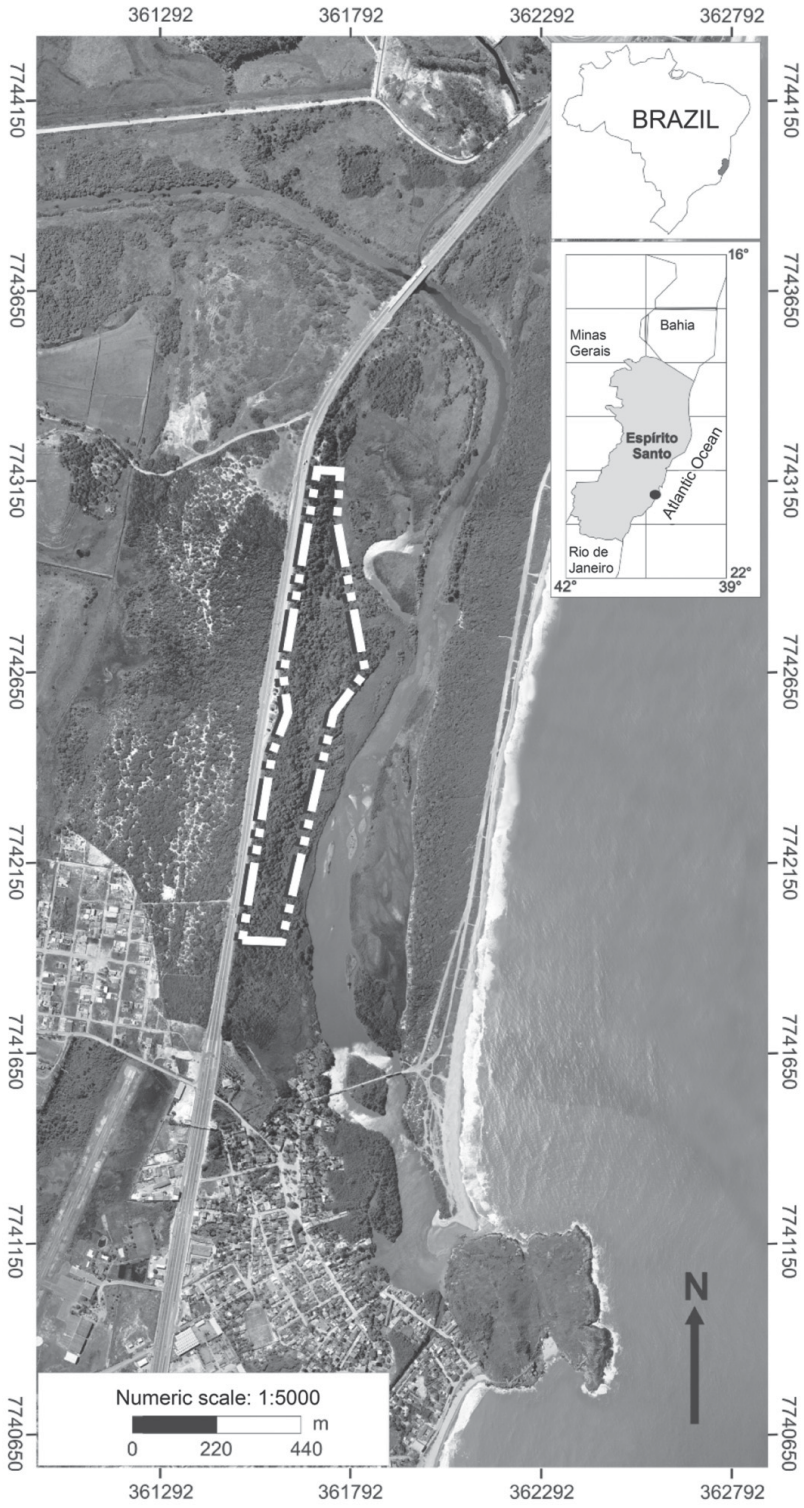

Figure 1. Location of Jacarenema Municipal Natural Park, city of Vila Velha, state of Espírito Santo, Brazil. In detail, the location of the forest areas studied. Source: Vila Velha City Hall.

the soil level) were included in the sampling. Because the cespitose (tuft-forming) growth of the palms of the genus Bactris makes the separation of individuals complicated and uncertain, each stalk was considered an individual.

The following formulas were used in order to delimitate the forest layers in each formation:

$$
\begin{gathered}
\text { lower layer }=h_{1}<(\bar{h}-s) \\
\text { middle layer }=(\bar{h}-s) \leq h_{1}<(\bar{h}+s) \\
\text { upper layer }=h_{1}>(\bar{h}+s)
\end{gathered}
$$

where $h_{1}$ is the combined heights of the sampled individuals, $\bar{h}$ is the mean of $h_{1}$, and $\mathrm{s}$ is the standard deviation of $h_{1}$. For a better understanding of the forest formations, 
Table 1. Classes of soil and fluctuation of the water table in the four forests within Jacarenema Municipal Natural Park, city of Vila Velha, state of Espírito Santo, Brazil.

\begin{tabular}{|c|c|c|c|c|c|}
\hline \multirow{3}{*}{ Formation } & \multirow{3}{*}{ Soil class } & \multirow{3}{*}{ Soil drainage class } & \multicolumn{3}{|c|}{ Fluctuation of the water table } \\
\hline & & & \multicolumn{3}{|c|}{$(\mathrm{m})$} \\
\hline & & & Max. & Min. & Annual mean \\
\hline Well-drained forest & SOQN & Excessively drained & -3.7 & -5 & -4.225 \\
\hline Transitional forest & DHIP & Moderate to imperfectly drained & -0.9 & -1.6 & -1.2375 \\
\hline Floodplain forest & SHTG & Poorly drained & 0.15 & -0.3 & -0.0625 \\
\hline Flooded forest & SSTH & Very poorly drained & 0.6 & -0.05 & 0.25 \\
\hline
\end{tabular}

Max. - maximum; Min. - minimum; SOQN - spodic orthic quartzarenic neosols; DHIP - duric hydromorphic illuvial-humus podzols; SHTG - sodic humic thionic gleysols; SSTH - solodic sapric thionic histosols.

we performed an analysis of the distribution of diameters. Except for the first class $(3.2<10 \mathrm{~cm})$, each diameter class spanned a range of $5 \mathrm{~cm}$.

The structure of the forests was analyzed regarding basal area and height of the sampled individuals, as well as density. The Shannon diversity index $\left(\mathrm{H}^{\prime}\right)$ and Pielou's evenness index $\left(J^{\prime}\right)$ were calculated in accordance with Brower \& Zar (1984).

We identified the botanical material by consulting the Herbarium of the Rio Doce Valley Nature Preserve (code, CVRD), the Herbarium of the Federal University of Espírito Santo (code, VIES) and the Herbarium of the Mello Leitão Museum of Biology (code, MBML), consulting the specific literature and sending specimens to specialists. The fertile material was deposited in the collection of the VIES Herbarium.

\section{Soil sample collection}

From each plot, three replicate soil samples were collected at a depth of $0-10 \mathrm{~cm}$ and submitted to chemical and physical analysis. The samples were air dried, crumbled when necessary and sieved through a $0.02 \mathrm{~mm}$-diameter sieve. The analyses were conducted in the Soil Science Department of the Federal University of Viçosa. The soil and the drainage of each forest formation were classified according to the Brazilian Soil Classification System (Embrapa 2006).

\section{Data analysis}

The pedological variations among the classes of soil on which the forests studied grew were evaluated with one-way ANOVA, followed by Tukey's post hoc test, in order to identify significant differences. The same procedure was used to determine the variations in the values of density, basal area and height of the individuals sampled in the forest formations analyzed. The Kruskal-Wallis non-parametric ANOVA was used to compare the values of soil drainage among the forest formations, and the multiple comparison test was used a posteriori to identify the differences.
Pearson's correlation coefficient was used in order to determine whether structural variables, including the Shannon diversity index, correlate with pedological characteristics and soil drainage. The individuals in the lower layer were not used in the analysis of vertical occupied space (height), to avoid underestimating the results on the development of the upper layer of the forests. The following chemical variables were used in the correlation tests: $\mathrm{pH}$, phosphorus, calcium, aluminum, sodium, magnesium, potassium and the amount of organic matter. The following physical (textural) variables were used: coarse sand, fine sand, silt and clay.

The data were tested for normal distribution by the Shapiro-Wilk test. Additionally, Levene's test was applied in order to evaluate the homoscedasticity of the data prior to the one-way ANOVA. In all tests, values of $\mathrm{p} \leq 0.05$ were considered statistically significant. All analyses were performed with the software BioEstat 5.0 (Ayres et al. 2007).

To determine the differences among the Shannon diversity index values obtained for each forest formation in the gradient, we employed a modified t-test (Magurran 1988). We also performed another test using the program EstimateS, version 8.0, with 100 randomizations, generating curves for the increase in diversity among the sampling units of each forest studied, with a $95 \%$ confidence interval for the standard deviation of each curve (Colwell 2006).

To identify variations in abundance and species richness among the studied forests, we used rank abundance curves (Whittaker plots), an efficient method for the comparison of the species diversity among different communities along environmental gradients (Magurran 2004).

\section{Results}

\section{Pedological gradient}

The chemical and physical variables of the soil indicated a gradient of fertility and physical characteristics among the forests studied (Tab. 2). The variability in the pedological characteristics observed was higher in the two forests subjected to flooding than in the forests not subjected to 
Table 2. Chemical and physical superficial variables of the soil $(0-10 \mathrm{~cm})$ in the four forests evaluated within Jacarenema Municipal Natural Park, city of Vila Velha, state of Espírito Santo, Brazil.

\begin{tabular}{|c|c|c|c|c|c|}
\hline Soil variables & Well-drained & Transitional & Floodplain & Flooded & $\mathrm{p}$ \\
\hline $\mathrm{pH}$ in $\mathrm{H}_{2} \mathrm{O}$ & $4.73 \pm 0.23 \mathrm{a}$ & $4.35 \pm 0.26 \mathrm{~b}$ & $3.78 \pm 0.12 \mathrm{c}$ & $4.06 \pm 0.24 \mathrm{~d}$ & $* *$ \\
\hline $\mathrm{P}\left(\mathrm{mg} / \mathrm{dm}^{3}\right)$ & $2.45 \pm 0.57 \mathrm{a}$ & $5.11 \pm 2.07 \mathrm{~b}$ & $9.44 \pm 3.09 \mathrm{c}$ & $9.37 \pm 2.40 \mathrm{c}$ & ** \\
\hline $\mathrm{K}\left(\mathrm{mg} / \mathrm{dm}^{3}\right)$ & $16.00 \pm 5.88 \mathrm{a}$ & $22.70 \pm 6.24 \mathrm{a}$ & $55.80 \pm 16.17 \mathrm{~b}$ & $74.30 \pm 32.56 \mathrm{c}$ & $* * *$ \\
\hline $\mathrm{Na}\left(\mathrm{mg} / \mathrm{dm}^{3}\right)$ & $6.89 \pm 5.42 \mathrm{a}$ & $8.69 \pm 4.68 \mathrm{a}$ & $60.90 \pm 12.76 \mathrm{~b}$ & $209.99 \pm 81.8 \mathrm{c}$ & $* *$ \\
\hline $\mathrm{Ca}\left(\mathrm{cmolc} / \mathrm{dm}^{3}\right)$ & $1.38 \pm 0.57 \mathrm{a}$ & $1.13 \pm 0.36 \mathrm{a}$ & $1.26 \pm 0.51 \mathrm{a}$ & $2.59 \pm 0.85 c$ & $* * *$ \\
\hline $\operatorname{Mg}\left(\mathrm{cmolc} / \mathrm{dm}^{3}\right)$ & $0.34 \pm 0.09 \mathrm{a}$ & $0.52 \pm 0.23 \mathrm{a}$ & $0.96 \pm 0.46 b$ & $2.72 \pm 0.85 \mathrm{c}$ & $* * *$ \\
\hline $\mathrm{Al}\left(\mathrm{cmolc} / \mathrm{dm}^{3}\right)$ & $0.19 \pm 0.17 \mathrm{a}$ & $0.87 \pm 0.64 \mathrm{~b}$ & $3.00 \pm 1.00 \mathrm{c}$ & $1.91 \pm 0.77 \mathrm{~d}$ & $* * *$ \\
\hline Organic matter $\left(\mathrm{dag} / \mathrm{Kg}^{-1}\right)$ & $2.39 \pm 0.52 \mathrm{a}$ & $5.07 \pm 2.81 \mathrm{a}$ & $35.07 \pm 12.12 b$ & $48.31 \pm 8.01 \mathrm{c}$ & $* * *$ \\
\hline Coarse sand (\%) & $90.00 \pm 1.03 \mathrm{a}$ & $88.00 \pm 2.34 \mathrm{a}$ & $42.50 \pm 13.68 \mathrm{~b}$ & $24.20 \pm 15.59 \mathrm{c}$ & $* *$ \\
\hline Fine sand (\%) & $4.90 \pm 0.72 \mathrm{a}$ & $5.10 \pm 1.17 \mathrm{a}$ & $17.20 \pm 12.75 b$ & $5.50 \pm 4.52 \mathrm{a}$ & ** \\
\hline Silt (\%) & $1.00 \pm 0.79 \mathrm{a}$ & $0.60 \pm 0.68 \mathrm{a}$ & $6.90 \pm 2.17 \mathrm{~b}$ & $16.70 \pm 3.92 \mathrm{c}$ & $* * *$ \\
\hline Clay (\%) & $4.10 \pm 1.07 \mathrm{a}$ & $6.30 \pm 2.60 \mathrm{a}$ & $33.40 \pm 9.01 \mathrm{~b}$ & $53.60 \pm 15.67 \mathrm{c}$ & $* * *$ \\
\hline
\end{tabular}

p represents the significance level with ANOVA. Letters within lines compare the means of the pedological variables for the forest formations analyzed with Tukey's test $(\mathrm{p}<0.05)$.

${ }^{*} \mathrm{p}<0.05 ;{ }^{* *} \mathrm{p}<0.01 ;{ }^{* * *} \mathrm{p}<0.001$.

flooding. The closeness of the water table to the surface in the illuvial-humus Podzols (transitional forest) was not enough to confer great pedological variations in comparison with the Quartzarenic Neosols (well-drained forest). The drainage classes varied significantly among the formations (Kruskal-Wallis; $\mathrm{p}<0.001$ ), and each forest displayed significant differences by the multiple comparison test at the 95\% confidence level.

The Melanic Gleysols (floodplain forest) and the Thionic Histosols (flooded forest) had higher acidity, as well as higher levels of exchangeable aluminum, organic matter, sodium, potassium, magnesium, silt and clay. These conditions accounted for high fertility to these soils in comparison with those of non-flooded; however, all classes of soils were considered dystrophic, with low nutrient status.

The Melanic Gleysols and the Thionic Histosols had higher levels of nutrients, as well as higher proportions of silt and clay, and were therefore less susceptible to leaching. Nevertheless, they were more limiting to the development of plant species, because of their toxicity, which is caused by their higher concentrations of aluminum, extreme acidity, salinity and high water table (it remains close to or at the surface during the entire year).

\section{Variations in structure}

The transitional forest and the floodplain forest had the highest values of height in the upper layer (Tab. 3). The variance among the four forest formations, in terms of the height of the individuals in the middle and upper layers, was significant $(\mathrm{p}<0.001)$, and Tukey's test indicated no significant difference only between the transitional forest and the floodplain forest.
The basal area varied significantly among the forests $(\mathrm{p}<0.001)$ : the floodplain forest had the highest basal area $\left(43.36 \mathrm{~m}^{2} \cdot \mathrm{ha}^{-1}\right)$, followed by the transitional forest $(36.23$ $\left.\mathrm{m}^{2} \cdot \mathrm{ha}^{-1}\right)$, the well-drained forest $\left(28.81 \mathrm{~m}^{2} \cdot \mathrm{ha}^{-1}\right)$ and the flooded forest $\left(20.52 \mathrm{~m}^{2} \cdot \mathrm{ha}^{-1}\right)$. Tukey's test indicated significant differences between the well-drained forest and the floodplain forest, as well as between the floodplain forest and the flooded forest ( $\mathrm{p}<0.001$ for both). A significant difference was also recorded between the floodplain forest and the transitional forest $(\mathrm{p}<0.001)$.

We sampled a total of 3804 individuals. The number of individuals increased along the flood gradient: 473 in the well-drained forest; 525 in the transitional forest; 832 in the floodplain forest; and 1974 in the flooded forest. The ANOVA showed a significant variance in the density of individuals among the studied forests $(\mathrm{p}<0.001)$. According to Tukey's test, there was no significant difference between the well-drained forest and the transitional forest, although there was a significant difference between the floodplain forest and the flooded forest $(\mathrm{p}<0.05)$.

The distributions of the diameters of the individuals sampled in the four studied forests tended to display an inverted "J" pattern, most of the individuals being concentrated in the smallest diameter classes (Fig. 2). There was a gradual increase in the number of individuals in the first class, together with a decrease in the representativeness of the individuals in the remaining classes, that paralleled the increase in the effect of the water table on the forest formation.

The heights of the individuals sampled in the forests correlated negatively and significantly with most of the environmental variables, whereas those heights correlated positively and significantly with coarse sand and drainage (Tab. 4). The total basal area showed a negative significant 
Table 3. Stratification of the individuals sampled in the four forests evaluated within Jacarenema Municipal Natural Park, city of Vila Velha, state of Espírito Santo, Brazil.

\begin{tabular}{|c|c|c|c|c|c|c|c|c|}
\hline \multirow{2}{*}{ Layer } & \multicolumn{2}{|c|}{ Well-drained } & \multicolumn{2}{|c|}{ Transitional } & \multicolumn{2}{|l|}{ Floodplain } & \multicolumn{2}{|l|}{ Flooded } \\
\hline & Height (m) & $\mathrm{NI}$ & Height $(\mathrm{m})$ & NI & Height $(\mathrm{m})$ & $\mathrm{NI}$ & Height (m) & NI \\
\hline Lower layer & Height $<3.9$ & 57 & Height $<3.2$ & 61 & Height $<2.5$ & 69 & Height $<2.0$ & 395 \\
\hline Middle layer & $3.9 \leq$ Height $<8.1$ & 228 & $3.2 \leq$ Height $<9.6$ & 351 & $2.5 \leq$ Height $<9.7$ & 633 & $2.0 \leq$ Height $<4.2$ & 1380 \\
\hline Upper layer & $8.1<$ Height & 188 & $9.6<$ Height & 113 & $9.7<$ Height & 130 & $4.2<$ Height & 199 \\
\hline Total & & 473 & & 525 & & 832 & & 1974 \\
\hline
\end{tabular}

$\mathrm{NI}$ - number of individuals.
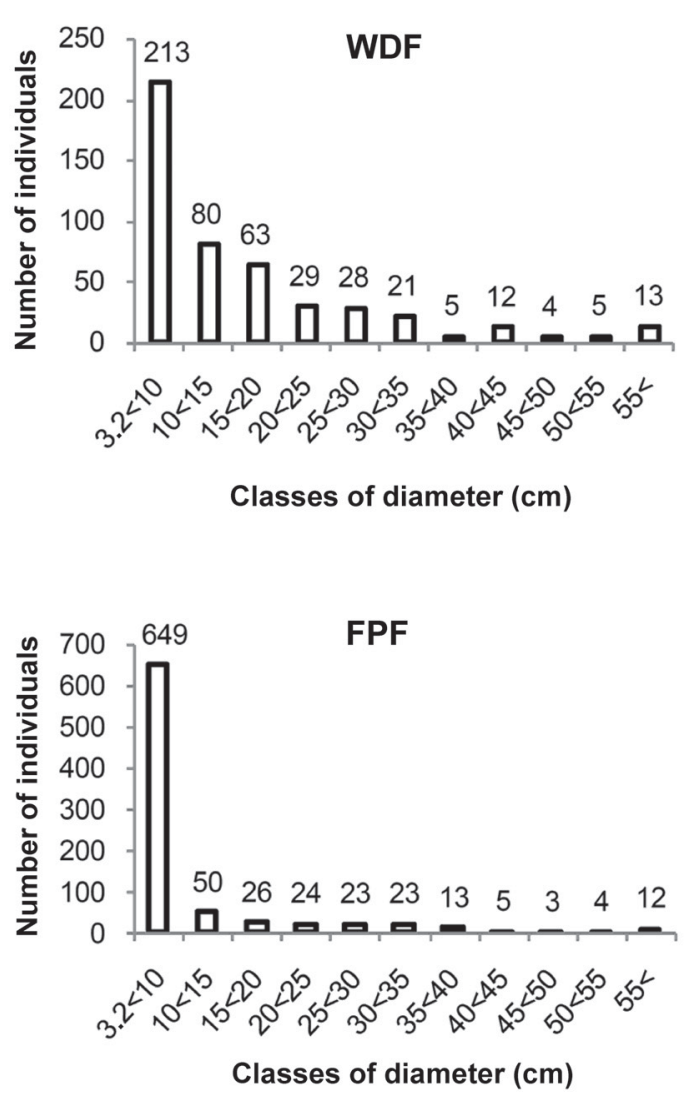
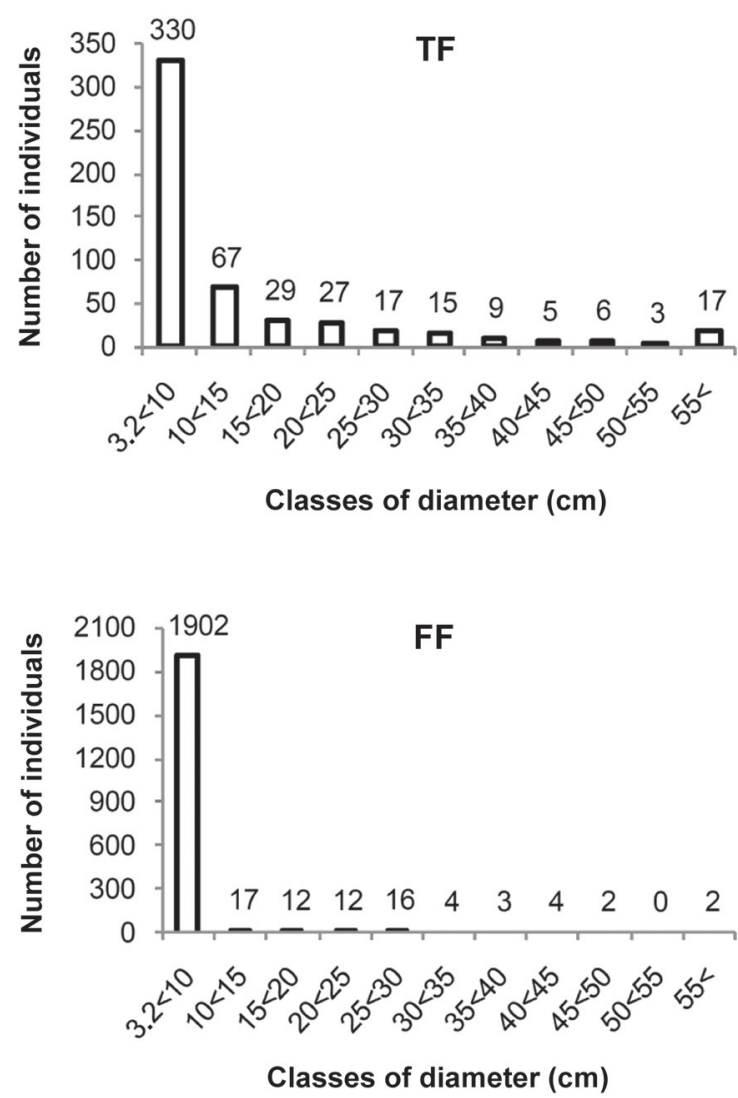

Figure 2. Distribution of the individuals sampled in four forests within Jacarenema Municipal Natural Park, Vila Velha, Espírito Santo, Brazil, by diameter.

$\mathrm{WDF}=$ well-drained forest $\mathrm{TF}=$ transitional forest $\mathrm{FPF}=$ floodplain forest $\mathrm{FF}=$ flooded forest.

correlation with $\mathrm{pH}$, sodium, calcium, magnesium and silt, correlating positively and significantly with aluminum and fine sand. The density of individuals correlated significantly with all variables except fine sand.

The greater development (in height and basal area) of the floodplain forest was associated with soil fertility, expressed by the levels of phosphorus, magnesium, sodium and potassium. The impaired development of the well-drained forest correlated positively with the decrease in nutrient availability in the soil. The flooded forest was the least developed, despite occurring on the soil with the highest nutrient availability.

\section{Variations in the diversity of the shrub and tree communities}

The diversity indices used indicated that the welldrained forest was the most diverse, followed by the transitional forest, the floodplain forest and the flooded forest (Tab. 5). The modified t-test showed that the diversity values varied significantly between the floodplain forest and the flooded forest, although not between the well-drained forest and the transitional forest. The distribution curve of the Shannon diversity index values corroborated the findings of the modified t-test, indicating higher diversities for the 
Table 4. Pearson's correlation coefficient ( $\mathrm{r}$ ) for height, basal area, density and the Shannon diversity index ( $\left.\mathrm{H}^{\prime}\right)$ with the environmental variables analyzed in the four forests within Jacarenema Municipal Natural Park, city of Vila Velha, state of Espírito Santo, Brazil.

\begin{tabular}{|c|c|c|c|c|c|c|c|c|}
\hline \multirow[t]{2}{*}{ Soil variables } & \multicolumn{2}{|c|}{$\begin{array}{l}\text { Height }^{*} \\
(\mathrm{~m})\end{array}$} & \multicolumn{2}{|c|}{$\begin{array}{c}\text { Total basal area } \\
\qquad\left(\mathrm{m}^{2}\right)\end{array}$} & \multicolumn{2}{|c|}{$\begin{array}{c}\text { Density } \\
\text { (n of individuals/area) }\end{array}$} & \multicolumn{2}{|c|}{$\mathrm{H}^{\prime}$} \\
\hline & $\mathrm{r}$ & $\mathrm{p}$ & $\mathrm{r}$ & $\mathrm{p}$ & $\mathrm{r}$ & $\mathrm{p}$ & $\mathrm{r}$ & $\mathrm{p}$ \\
\hline $\mathrm{pH}$ in $\mathrm{H}_{2} \mathrm{O}$ & -0.019 & ns & -0.221 & $* *$ & -0.364 & $* * * *$ & 0.73 & $* * * *$ \\
\hline $\mathrm{P}$ & -0.275 & $* * *$ & -0.002 & ns & 0.525 & $* * * * *$ & -0.75 & $* * * *$ \\
\hline K & -0.401 & $* * * *$ & -0.040 & ns & 0.690 & $* * * * *$ & -0.70 & $* * * *$ \\
\hline $\mathrm{Na}$ & -0.687 & $* * * *$ & -0.326 & $* * *$ & 0.791 & $* * * * *$ & -0.72 & $* * *$ \\
\hline $\mathrm{Ca}$ & -0.666 & $* * * *$ & -0.443 & $* * * *$ & 0.536 & $* * * * *$ & -0.54 & $* * * *$ \\
\hline $\mathrm{Mg}$ & -0.698 & $* * * *$ & -0.375 & $* * * *$ & 0.721 & $* * * * *$ & -0.79 & $* * * *$ \\
\hline $\mathrm{Al}$ & 0.018 & ns & 0.233 & ** & 0.329 & $* * * *$ & -0.66 & $* * * *$ \\
\hline Organic matter & -0.524 & $* * * *$ & -0.121 & ns & 0.711 & $* * * * *$ & -0.88 & $* * *$ \\
\hline Coarse sand & 0.537 & $* * * *$ & 0.127 & ns & -0.732 & $* * * * *$ & 0.86 & $* * *$ \\
\hline Fine sand & 0.140 & ns & 0.264 & $* * *$ & 0.055 & ns & -0.11 & ns \\
\hline Silt & -0.691 & $* * * *$ & -0.319 & $* * *$ & 0.788 & $* * * *$ & -0.90 & $* * *$ \\
\hline Clay & -0.570 & $* * * *$ & -0.174 & ns & 0.732 & $* * * * *$ & -0.85 & $* * *$ \\
\hline Drainage & 0.294 & $* * *$ & -0.006 & ns & -0.633 & $* * * * *$ & 0.73 & $* * * *$ \\
\hline
\end{tabular}

ns - non-significant.

${ }^{*}$ Height values correspond to individuals in the middle and upper layers only.

${ }^{* *} \mathrm{p}<0.05 ;{ }^{* * *} \mathrm{p}<0.01 ;{ }^{* * * *} \mathrm{p}<0.001 ;{ }^{* * * * *} \mathrm{p}<0.0001$.

Table 5. Diversity and richness indices for the four forests evaluated within Jacarenema Municipal Natural Park, city of Vila Velha, state of Espírito Santo, Brazil. ${ }^{*}$

\begin{tabular}{ccccc}
\hline \multirow{2}{*}{ Diversity } & \multicolumn{3}{c}{ Forest formation } \\
\cline { 2 - 5 } & Well-drained & Transitional & Floodplain & Flooded \\
\hline Richness (n of species) & 74 & 82 & 47 & 29 \\
Diversity (H') & $3.65 \mathrm{a}$ & $3.56 \mathrm{a}$ & $2.25 \mathrm{~b}$ & $0.55 \mathrm{c}$ \\
Uniformity (H') & 1.32 & 1.28 & 0.78 & 0.19 \\
Variance (H') & 0.0024 & 0.0032 & 0.0029 & 0.0011 \\
Evenness (J') & 0.848 & 0.808 & 0.583 & 0.162 \\
\hline
\end{tabular}

${ }^{*}$ Different letters in the same row indicate statistically significant differences among the forest formation types, according to the modified $\mathrm{t}$-test ( $\mathrm{p}<0.05$ ).

forests not subjected to flooding (Fig. 3). This tendency was supported by the J' and by the rank abundance curve (Fig. 4).

All variables except fine sand correlated significantly with diversity (Tab. 4). The highest diversities correlated with lower nutrient availability in the soil, although the soils with the lowest nutrient availability had less aluminum, presented higher pHs and were unaffected by flooding.

\section{Discussion}

The edaphic conditions found in the well-drained and transitional forests seem to be less restrictive; however, the soils of these forests are also less fertile and thus limit the structural development of plant formations (Scarano 2002). The results obtained by analyzing the soil drainage reinforce the strong ecological characteristics conferred to these forests by the Jucu river annual flooding causing the elevation of the water table. In addition to flooding, factors such as high concentration of aluminum, extreme acidity and salinity soils are widely mentioned as restrictive to the structural development of the vegetation and to species diversity (Scarano 2002; Ivanauskas et al. 1997).

The difference in soil fertility among the forest formations can considered one of the main factors in the variations of the structural development, where height and basal area increase, until a certain point, according to the nutrient availability in the soil. However, the excess of nutrient availability in the soil can lead to a decrease in the biomass of plant communities (Roem \& Berendse 2000), as observed in the restinga forests here studied, where the highest values of basal area and height were found in the intermediate conditions of nutrient availability in the soil (transitional forest and well-drained forest). The relationship between vegetation biomass and soil shown by Roem \& Berendse (2000) explains the result obtained for the flooded forest, which 


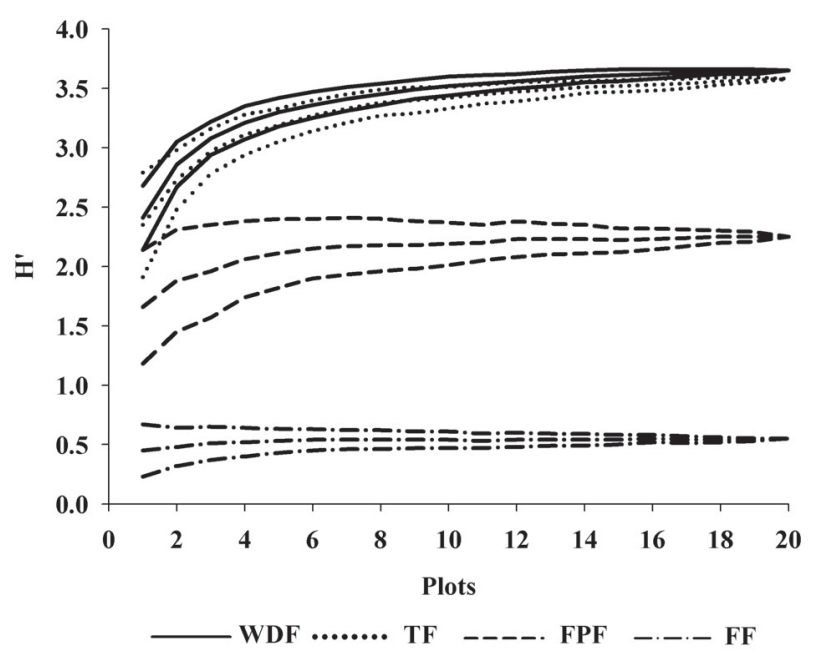

Figure 3. Distribution of the Shannon diversity index $\left(\mathrm{H}^{\prime}\right)$ in the plots of four forests sampled within Jacarenema Municipal Natural Park, city of Vila Velha, state of Espírito Santo, Brazil. The curves were generated with a 95\% confidence interval.

$\mathrm{WDF}=$ well-drained forest; $\mathrm{TF}=$ transitional forest; $\mathrm{FPF}=$ floodplain forest; $\mathrm{FF}=$ flooded forest.

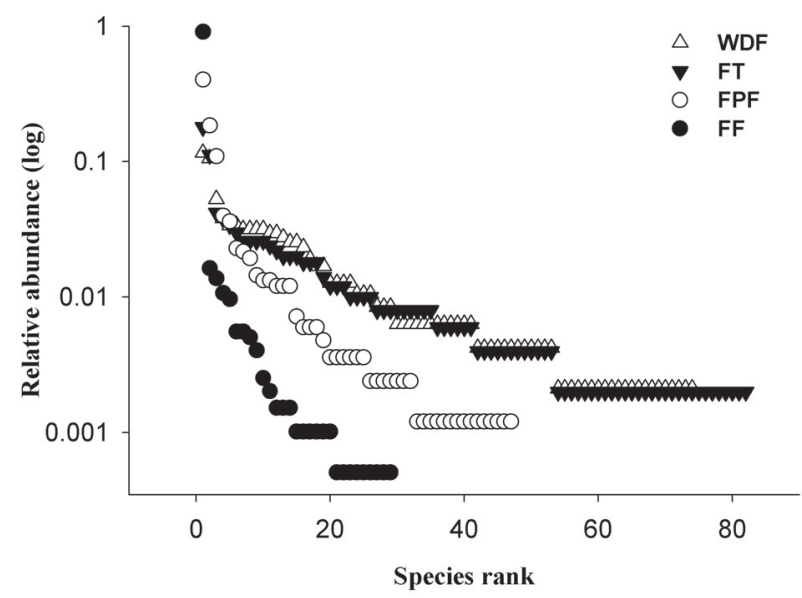

Figure 4. Species rank abundance in four forests sampled within Jacarenema Municipal Natural Park, city of Vila Velha, state of Espírito Santo, Brazil. $\mathrm{WDF}=$ well-drained forest; $\mathrm{TF}=$ transitional forest; $\mathrm{FPF}=$ floodplain forest; $\mathrm{FF}=$ flooded forest.

was the least developed, in terms of basal area and height, of the studied forests, despite occurring on more fertile soil.

One of the factors that might have affected the structural development of the flooded forest was the decrease in oxygen availability in the soil related to the persistence of the water table at the surface level in that forest. The responses of plants to low oxygen in the soil include hypotrophy of the trunk and stunted growth (Kramer 1983), as well as the appearance of aerial roots in some species (Araujo et al. 1998). Another factor that contributes to the constrained development of the vegetation and lower species diversity in the flooded forest is the increase in sodium content, considering that the tree species found in this formation are not known to be halophytic (adapted to saline environments). The absorption of salts by non-halophytic plant species might in moderate to severe impairment of their growth and development (Parida \& Das 2005).

Within the restinga ecosystem, greater development of floodplain forests (in height and basal area) in comparison with well-drained forests and flooded forests has been reported for various sites along the coast of Brazil (Britez et al. 1997; Araujo et al. 1998; Sztutman \& Rodrigues 2002; Menezes-Silva \& Britez 2005). The better development of well-drained forests in which the water table is close to the surface, as found in the transitional forest in the present study, was also reported by Guedes et al. (2006) for the restinga in the town of Bertioga, in the state of São Paulo.

The high density of the flooded forest might be a response to the low number of individuals with higher values of basal area and height, which created a space (niche) for the occupation of smaller-sized individuals. In forests along flood gradients, the density of individuals increases with an increase in the length of time that the water table remains at the surface (Sztutman \& Rodrigues 2002; Bianchini et al. 2003; Dorneles \& Waechter 2004a, 2004b; Rocha et al. 2005; Carvalho et al. 2006; Silva et al. 2007).

The results obtained evidenced that species diversity $\left(H^{\prime}\right)$ is correlated with the environmental gradient, with lower values of diversity in flooded areas. These environments impose the strongest abiotic limitations for the establishment of plant species, because their soils are more toxic (because of higher aluminum concentrations), extremely acidic, saline and drainage deficient. Therefore, those were most important factors in limiting the diversity than the low fertility and the hydric limitation that exists in the well-drained forests in the restinga.

For environments subjected to flooding, various authors have found diversity values that were lower than those obtained in the present study (Toniato et al. 1998; Romagnolo \& Souza 2000; Sztutman \& Rodrigues 2002; Bianchini et al. 2003; Dorneles \& Waechter 2004a; Carvalho et al. 2006). Diversity can be lower or higher according to the persistence of the water in the system: poor drainage results in lower diversity. Soil attributes such as acidity, levels of sodium and aluminum have also been mentioned as limiting factors for the establishment of plant species (Lathwell \& Grove 1986; Sollins 1998; Roem \& Berendse 2000).

In the present study, the was a negative correlation between soil fertility and diversity, in opposition to the proposal made by Tilman (1982). The higher diversity found in the well-drained forest refutes the theories put forth by Ashton (1990) and Tilman (1986), who suggested that environments with intermediate nutrient availability display higher species diversity than do environments with higher or lower nutrient availability.

The low diversity found in the flooded forest and in the floodplain forest indicate that the stress factors in these communities favor a small group of species that tolerate the 
specific edaphic conditions in these forests, to the extent that some species demonstrated a high capacity to colonize these types of environments, as shown by the values of evenness index, diversity index and rank abundance curves. This high expression of a few species is characteristic of habitats subjected to extreme environmental conditions (Hart 1990; Ferreira \& Stohlgren 1999; Scarano 2002).

In this context, the structural variations in the four forest communities here studied were correlated with the edaphic variables. Although flooding seemed to be the main determining factor of the gradient, the chemical and physical variables of the soil contributed significantly to the results obtained.

The most important of the environmental variables tested was flooding, because it affects oxigen and nutrient availability, the amount of organic matter and texture of the soil classes in the restinga studied. The nutrient availability in the soil was not a restrictive factor for the establishment of species in the restinga forests, considering that the highest diversity was obtained in the soils with lower nutrient availability but with lower stress. Flooding and higher levels of sodium and aluminum were marked factors in the forests subjected to flooding. This condition indicates that the edaphic factors exert stronger species selection in the forests subjected to flooding.

Nutrient availability is important for the structural differentiation of the forests studied. The values of height and basal area of individuals were higher in the areas of intermediate accumulation of nutrients in the soil (transitional forest and floodplain forest) and decreased towards the extremes of the gradient.

\section{Acknowledgements}

This study received financial support from the Brazilian Coordenação de Aperfeiçoamento de Pessoal de Nível Superior (CAPES, Office for the Advancement of Higher Education). The authors thank Mariana F. Rocha, Fabio A. Matos, Herivelton Borges, Geanna Correia, Marcelo Belisário and André Assis, for assisting in the field activities; and the city of Vila Velha, for authorizing the study in Jacarenema Municipal Natural Park.

\section{References}

Araujo, D.S.D.; Scarano, F.R.; Sá, C.F.; Kurtz, B.C.; Zaluar, H.L.T.; Montezuma, R.C.M. \& Oliveira, R.C. 1998. Comunidades vegetais do Parque Nacional da Restinga de Jurubatiba. Pp. 39-62. In: Esteves, F.A. (Ed.). Ecologia das Lagoas Costeiras do Parque Nacional da Restinga de Jurubatiba e do Município de Macaé, RJ. Universidade Federal do Rio de Janeiro, Rio de Janeiro.

Ashton, P.S. 1990. Species richness in tropical forests. Pp.239-251. In: Holm-Nielsen, L. B.; Nielsen, I. C. \& Balslev, H. (Eds.). Tropical forests - botanical dynamics, speciation and diversity. London, Academic Press.

Ayres, M.; Ayres Jr.; M., Ayres, D.M. \& Santos, A.S. 2007. BioEstat 5.0: aplicações estatísticas nas áreas das ciências biológicas e médicas. Brasília, Sociedade Civil Mamirauá. Belém. CNPq.
Bianchini, E.; Popolo, R.S.; Dias, M.C.; Pimenta, J.A. 2003. Diversidade e estrutura de espécies arbóreas em área alagável do município de Londrina, sul do Brasil. Acta Botanica Brasilica 17(3): 405-419.

Bigarella, J. J. 2001. Contribuição ao estudo da planície litorânea do Estado do Paraná. Brazilian Archives of Biology and Technology, Jubilee Volume (1946-2001): 65-110.

Blom, C.W. P. M. \& Voesenek, L.A.C.J. 1996. Flooding: the survival strategies of plants. Trends in Ecology \& Evolution 11(7): 290-295.

Britez, R.M.; Santos Filho, A.; Reissmann, C.B.; Silva, S.M; Athayde, S.F.; Lima, R.X. \& Quadros, R.M.B. 1997. Nutrientes no solo de duas florestas da planície litorânea da Ilha do Mel, Paranaguá, PR. Revista Brasileira de Ciência do Solo 21(4): 625-634.

Brower, J. E. \& Zar, J. H. 1984. Field \& laboratory methods for general ecology. 2 ed. Wm. C. Brown Publishers, Dubuque, Iowa.

Budke, J.C.; Jarenkow, J.A. \& Oliveira-Filho, A.T. 2007. Relationships between tree component structure, topography and soils of a riverside forest, Rio Botucaraí, Southern Brazil. Plant ecology 189: 187-200.

Carvalho, F.A.; Nascimento, M.T.; Braga, J.M.A. \& Rodrigues, P.J.F.P. 2006. Estrutura da comunidade arbórea da Floresta Atlântica de baixada periodicamente inundada na Reserva Biológica de Poço das Antas, Rio de Janeiro, Brasil. Rodriguésia 57(3): 503-518.

Colwell, R. K. 2006. EstimateS: statistical estimation of species richness and shared species from samples. Version 8.0 User's Guide and application published at: http://viceroy.eeb.uconn.edu/estimates.

Dorneles, L.P.P. \& Waechter, J.L. 2004a. Fitossociologia do componente arbóreo na floresta turfosa do Parque Nacional da Lagoa do Peixe, Rio Grande do Sul, Brasil. Acta Botanica Brasilica 17(4): 815-824.

Dorneles, L.P.P. \& Waechter, J. L. 2004b. Estrutura do componente arbóreo da floresta arenosa de restinga do Parque Nacional da Lagoa do Peixe, Rio Grande do Sul. Hoehnea 31(1): 61-71.

EMBRAPA. 2006. Sistema brasileiro de classificação de solos. 2.ed. Rio de Janeiro: EMBRAPA Solos.

Ferreira, L.V. \& Stohlgren, Thomas J. 1999. Effects of river level fluctuation on plant species richness, diversity, and distribution in a floodplain forest in Central Amazonia. Oecologia 120(4): 582-587.

Gomes, F.H.; Vidal-Torrado, P.; Macías, F.; Gherardi, B. \& Perez, X.L.O 2007. Solos sob vegetação de Restinga na Ilha do Cardoso (SP). I - caracterização e classificação. Revista Brasileira de Ciências do Solo 31: 1563-1580

Gomes, J.B.; Resende, M.; Rezende, S.B. \& Mendonça, E.S. 1998. Solos de três áreas de Restinga. I. Morfologia, caracterização e classificação. Pesquisa Agropecuária Brasileira 33: 1907-1919.

Guedes, D.; Barbosa, L.M.; Martins, S.E. 2006. Composição florística e estrutura fitossociológica de dois fragmentos de floresta de restinga no $\mathrm{Mu}$ nicípio de Bertioga, SP, Brasil. Acta Botanica Brasilica 20(2): 299-311.

Hart, T.B. 1990. Monospecific dominance in tropical rain forests. Trends in Ecology \& Evolution 5: 6-11.

Huston, M. 1980. Soil nutrients and tree species richness in Costa Rica forests. Journal of Biogeography 7: 147-157.

IPEMA (Instituto de Pesquisas da Mata Atlântica) 2005. Conservação da Mata Atlântica no Estado do Espírito Santo: cobertura florestal e unidades de conservação. Programa Centros para Conservação da Biodiversidade - Conservação Internacional do Brasil. Vitória, IPEMA.

Ivanauskas, N.M.; Rodrigues, R.R. \& Nave, A.G. 1997. Aspectos ecológicos de um trecho de floresta de brejo em Itatinga, SP: florística, fitossociologia e seletividade de espécies. Revista Brasileira de Botânica 20(2): 139-153.

Kramer, P.J. 1983. Water relations of plants. New York, Academic Press.

Lathwell, D.J \& Grove, T.L. 1986. Soil-Plant Relationships in the Tropics. Annual Review of Ecology and Systematics 17: 1-16.

Leão, Z.M.A.N. \& Dominguez, J.M.L. 2000. Tropical coast of Brazil. Mar Poll Bull 41: 112-122.

Magnago, L.F.S.; Martins, S.V.; Schaefer, C.E.G.R. \& Neri, A.V. 2010. Gradiente fitofisionômico-edáfico em formações florestais de Restinga no Sudeste do Brasil. Acta Botanica Brasilica 24(3): 734-746.

Magnago, L.F.S.; Pereira, O.J.; Matos, F.A.R. \& Souza, P.F. 2007. Caracterização Fitofisionômica da Restinga na Morada do Sol, Vila Velha/ES. Revista Brasileira de Biociências 5(supl.1): 456-458.

Magnago, L.F.S.; Martins, S.V.; Schaefer, C.E.G.R.; Neri, A.V. 2012. Restinga forests of the Brazilian coast: richness and abundance of tree species on different soils. Anais da Academia Brasileira de Ciências 84: 807-822. 
Magurran, A.E. 1988. Ecological diversity and its measurement. New Jersey, Princeton University.

Magurran, A.E. 2004. Measuring biological diversity. Oxford, Blackwell Science, 256p.

Martin, L.; Suguio, K.; Dominguez, J.M.L. \& Flexor, J-M. 1997. Geologia do Quaternário costeiro do litoral norte do Rio de Janeiro e do Espírito Santo. Belo Horizonte, CPRM/FAPESP.

Menezes-Silva, S. \& Britez, R.M. 2005. A vegetação da planície costeira. Pp. 49-84. In: Marques, M.C.M. \& Britez, R.M. (Orgs.). História natural e conservação da Ilha do Mel. Curitiba, UFPR.

Mueller-Dombois, D. \& Ellenberg, H. 1974. Aims and methods of vegetation ecology. New York, J. Wiley \& Sons.

Parida, A.K. \& Das, A.B. 2005. Salt tolerance and salinity effects on plants: a review. Ecotoxicology and Environmental Safety 60: 324-349.

Pereira, O.J. 2003. Restinga: origem, estrutura e diversidade. Pp. 177-179. In: Jardim, M.G.; Bastos; M.N. C. \& Santos, J.U.M. (Orgs.). Desafios da botânica brasileira no novo milênio: inventário, sistematização e conservação da biodiversidade vegetal. Belém, Sociedade Brasileira de Botânica.

Pezeshki, S. R. 2001. Wetland plant responses to soil flooding. Environmental and Experimental Botany 46: 299-312.

Reis, R.C.C. 2006. Palmeiras (Arecaceae) das Restingas do Estado do Rio de Janeiro, Brasil. Acta Botanica Brasilica 20(3): 501-512.

Rocha, C.T.V.; Carvalho, D.A.; Fontes, M.A.L.; Oliveira-Filho, A.T.; Van Den Berg \& Marques, J.J.G.S.M. 2005. Comunidade arbórea de um continuum entre floresta paludosa e de encosta em Coqueiral, Minas Gerais, Brasil. Revista Brasileira de Botânica 28(2): 203-218.

Roem, W.J. \& Berendse, F. 2000. Soil acidity and nutrient supply ratio as possible factors determining changes in plant species diversity in grassland and heathland communities. Biological Conservation 92: 151-161.
Romagnolo, M.B.; Souza, M.C. 2000. Análise florística e estrutural de florestas ripárias do Alto Rio Paraná, Taquaruçu, MS. Acta Botanica Brasilica 14(2): 163-174.

Rossi, M. 1999. Fatores formadores da paisagem litorânea: A bacia do Guaratuba, São Paulo - Brasil. Tese de Doutorado, Universidade de São Paulo, São Paulo.

Scarano, F.R. 2002. Structure, Function and Floristic Relationships of Plant Communities in Stressful Habitats Marginal to the Brazilian Atlantic Rainforest. Annals of Botany 90: 517-524.

Silva, A.C.; Van Den Berg, E.; Higuchi, P. \& Oliveira-Filho, A.T. 2007. Comparação florística de florestas inundáveis das regiões Sudeste e Sul do Brasil. Revista Brasileira de Botânica 30(2): 257-269.

Sollins, P. 1998. Factors influencing species composition in tropical lowland rain forest: does soil matter? Ecology 79(1): 23-30.

Stevens, M.H.H. \& Carson, W.P. 1999. Plant density determines species richness along an experimental fertility gradient. Ecology 80(2): $455-465$

Sztutman, M. \& Rodrigues, R.R. 2002. O mosaico vegetacional numa área de floresta contínua da planície litorânea, Parque Estadual da Campina do Encantado, Pariquera - Açu, SP. Revista Brasileira de Botânica 25(2): 61-176.

Tilman, D. 1982. Resource competition and community structure. Monographs in Population Biology. Princeton, Princeton University Press.

Tilman, D. 1986. Evolution and differentiation in terrestrial plant communities: the importance of the soil resource: light gradient. Pp.359-380. In: Diamond, J. \& Case T.J. (Eds.). Community ecology. New York, Harper and Row.

Toniato, M.T.Z.; Leitão-Filho, H.F. \& Rodrigues, R.R. 1998. Fitossociologia de um remanescente de floresta higrófila (Mata de brejo) em Campinas, SP. Revista Brasileira de Botânica 21(2): 197-210. 